Die

\title{
hriftlidge Lehre
}

we?

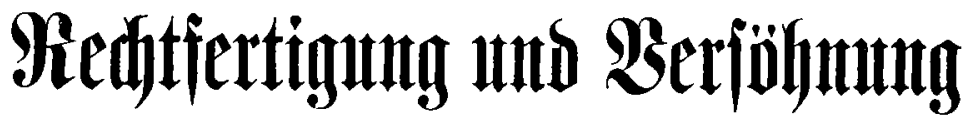

Dorgeitclit

non

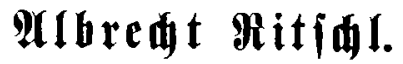

3weite berbejĩerte $\mathfrak{A} u$ flage.

Bweiter Band.

Der biblifde Stoff ber Rehre.

$\mathfrak{B}$ ○n $\mathfrak{\pi}$,

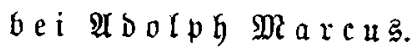

1882. 
Das Ređt ber Heberickung bleibt vorbehaltert. 